\title{
Characterisation of the influence of anti-gastrin, anti-epidermal growth factor, anti-oestradiol, and anti-luteinising hormone releasing hormone antibodies on the proliferation of 27 cell lines from the gastrointestinal tract
}

\author{
F Darro, I Camby, A Kruczynski, J-L Pasteels, J Martinez, R Kiss
}

Montpellier, France

J Martinez

Correspondence to:

Dr R Kiss, Laboratory of

Histology, Faculty of

Medicine, Free University of

Brussels, 808 route de

Lennik, 1070 Brussels,

Belgium.

Accepted for publication

9 June 1994

Keywords: gastrointestinal tract, hormones, growth factors, cell lines.

It has become clearly established that gastrin plays an important part in the growth control of normal and malignant gastrointestinal mucosa ${ }^{1-4}$ since the description of the presence

\begin{abstract}
Division de
Cancérologie

Expérimentale 1,

Centre de Recherche

Pierre Fabre, Castres,

France

F Darro

A Kruczynski

Laboratoire

d'Histologie, Faculté

de Médecine,

Université Libre de

Bruxelles, Brussels,

Belgium

I Camby

J-L Pasteels

R Kiss

\section{Chimie et}

Pharmacologie de

Molecules, D'interet

Biologique, URA 1845

Faculté de Pharmacie,

Abstract

Numerous data from published reports prove that the proliferation of gastrointestinal tumour cell lines are under the control of many hormones or growth factors, or both. Most of these publications report the influence on a very small number of cell lines of one or two such factors only. This work deals with the in vitro characterisation of the influence of the anti-gastrin, the anti-epidermal growth factor (EGF), the anti-oestradiol $\left(E_{2}\right)$, and the anti-luteinising hormone releasing hormone (LHRH) antibodies on the proliferation of a large series of gastrointestinal cell lines. Cell proliferation was assessed by means of the colorimetric MTT assay on a series of 27 gastrointestinal cell lines obtained from the American Type Culture Collection (ATCC). Of the 27 cell lines, the antiastrin, the anti-EGF, the anti- $E_{2}$, and the anti-LHRH neutralising antibodies considerably influenced the proliferation of $13,25,12$, and 16. No gastrointestinal cell line was unresponsive to the four antibodies simultaneously. The anti-gastrin and anti-EGF antibody induced effects on the 27 gastrointestinal cell line proliferation were significantly correlated, as was also the case for the anti- $E_{2}$ and anti-LHRH antibody induced effects. Of the anti-gastrin, the anti-EGF, the anti$E_{2}$, and the anti-LHRH antibodies, it was the anti-EGF one that had the greatest influence, both quantitatively and qualitatively, on gastrointestinal cell proliferation. The correlation of the effects of definite anti-hormone antibodies is suggestive of a common mechanism of action for the corresponding hormones and casts some doubt on the efficiency of anti-hormone monotherapy. (Gut 1995; 36: 220-230)
\end{abstract}

of gastrin receptors in rats' stomachs. ${ }^{5}$ This role is mediated through the gastrin receptors $^{6-9}$ and is exerted by an autocrine action mechanism. ${ }^{10-12}$ Furthermore, recent data show that gastrointestinal tumour cells, and especially colorectal ones, are also sensitive to hormones or growth factors, or both like the transforming growth factors alpha and beta, ${ }^{13-16}$ the insulin like growth factors I and II, ${ }^{13} 17$ the basic fibroblast growth factor, ${ }^{18}$ and many others. In addition to these growth factors two additional ones are also well known as stimulants of gastrointestinal cell line proliferation. These are oestradiol $\left(\mathrm{E}_{2}\right)^{19-21}$ and the epidermal growth factor (EGF), 2223 for both of which specific receptors exist in normal and neoplastic gastrointestinal mucosa. ${ }^{14}$ 24-26 We recently showed that the luteinising hormone releasing hormone (LHRH) can also considerably modulate colorectal cell proliferation. ${ }^{21}$

Referring to the results contained in published works, Frucht et $a^{27}$ state that they are limited because it often happens that only a small number of tumours are studied, only one or two receptors are sought, and the effect on cell function is not investigated. In their study of 10 recently characterised human colon cancer cell lines undertaken to discover if they possessed receptors for any of 12 different gastrointestinal hormones or neurotransmitters, these authors ${ }^{27}$ show on these cell lines the presence of several different receptors that are functional because occupation by selective agonists has changed the intracellular mediators. While they ${ }^{27}$ consider it necessary to extend their studies to evaluate growth effects, we have taken this as the goal of this work, which deals with the in vitro characterisation of the influence of the gastrin, the EGF, the $E_{2}$, and the LHRH on the proliferation of 27 gastrointestinal cell lines obtained from the American Type Culture Collection (ATCC). We preferred to add the anti-hormone or antigrowth factor antibody, or both in the culture medium rather than the hormone or growth factor itself because more information is available in this way. Indeed, a significant hormone or growth factor induced effect, or both on a given cell line proliferation shows that the proliferation of this cell line is 'sensitive' to the addition of this hormone or growth factor, but does not show if such proliferation was already under the influence of this hormone or growth 
TABLE I Description and origin of the 27 cell lines under study

\begin{tabular}{llllll}
\hline Name & ATCC code & Species & Histopathology & Tissue of origin & Reference no \\
\hline SW403 & CCL230 & H & C & Colon & 31 \\
AGS & CRL1739 & H & C & Stomach & 32 \\
SW1463 & CCL234 & H & C & Colon & 31 \\
CH1ES & CCL73 & G & N & Oesophagus & 33 \\
SW48 & CCL231 & H & C & Colon & 31 \\
DLD-1 & CCL221 & H & C & Colon & 34 \\
GPC-16 & CCL242 & GP & C & Colon & 35 \\
Colo320 & CCL220 & H & C & Colon & 36 \\
LS123 & CCL255 & H & A & Colon & 37 \\
SNU-C2B & CCL250 & H & A & Caecum & 38 \\
HT-29 & HTB29 & H & C & Colon & 39 \\
Colo201 & CCL224 & H & C & Colon & 40 \\
Colo205 & CCL222 & H & C & Colon & 40 \\
IA-Xs-SBR & CRL1677 & R & C & Small intestine & 41 \\
NCI-H508 & CCL253 & H & C & Caecum & 38 \\
WiDR & CCL218 & H & C & Colon & 42 \\
SW1417 & CCL238 & H & C & Colon & 31 \\
HCT-116 & CCL247 & H & A & Colon & 43 \\
LS180 & CL187 & H & C & Colon & 44 \\
SW948 & CCL237 & H & C & Colon & 31 \\
CMT-93 & CCL223 & M & A & Rectum & 45 \\
HCT-8 & CCL244 & H & C & Ileum & 46 \\
LS174T & CL188 & H & C & Colon & 44 \\
HuTu80 & HTB40 & H & C & Duodenum & 47,48 \\
T84 & CCL248 & H & A & Colon & 49 \\
SW1116 & CCL233 & H & C & Colon & 31 \\
NCI-H747 & CCL252 & H & C & Caecum & 38 \\
& & & & & \\
\hline
\end{tabular}

The gastrointestinal cell lines are ranked from the top to the bottom of the Table according to their increasing sensitivity to gastrin as is shown in Figures 1-7 and Table II. With respect to their increasing sensitivity to gastrin as is shown in Figures $1-7$ and Table II. With respect to histopathology, $N=$ normal, $C=$ carcinoma, and $A=$ adenocarcing
$\mathrm{H}=$ human, $\mathrm{GP}=$ guinea pig, $\mathrm{R}=$ rat, $\mathrm{M}=$ mouse, and $\mathrm{G}=$ goat.

factor present in the medium or secreted by autocrine or paracrine mechanisms, or both.

It should be emphasised that these antibodies would not cross the cell membrane and therefore, if there are intracrine mechanisms linked with some of these hormones, then these antibodies would not affect such a mechanism.

Cell proliferation was assessed by means of the colorimetric MTT assay. ${ }^{28-30}$

\section{Methods}

CELIS AND MEDIUM

All the 27 gastrointestinal cell lines were obtained from the ATCC (Rockville, MD). Table I lists and describes the cell lines. The 27 cell lines were adapted to grow as monolayers cultured at $37^{\circ} \mathrm{C}$ in closed Falcon plastic dishes (Nunc, Poly Labo, Strasbourg, France) containing Eagle's minimal essential medium (Gibco, Cergy Pontoise, France) supplemented with $10 \%$ fetal calf serum (Gibco)

All the mediums were supplemented with a mixture of $0.6 \mathrm{mg} / \mathrm{ml}$ glutamine (Gibco), $200 \mathrm{IU} / \mathrm{ml}$ penicillin (Gibco), $200 \mu \mathrm{g} / \mathrm{ml}$ streptomycin (Gibco), and $0.1 \mathrm{mg} / \mathrm{ml}$ gentamycin (Gibco). The fetal calf serum was heat inactivated for one hour at $56^{\circ} \mathrm{C}$.

\section{EXPERIMENTAL SCHEDULE FOR CELL GROWTH} ASSESSMENTS

Cell growth was assessed by means of the MTT assay as previously described ${ }^{30}$ - that is, according to Mosman ${ }^{28}$ with the modifications recommended by Carmichael et al. ${ }^{29}$ Briefly, after the incubation of the cells for 96 hours in the various mediums, the culture medium was removed and replaced with $100 \mu \mathrm{l}$ MTT (3-(4,5)-dimethylthiazol-2-yl)-2,5-diphenyl tetrazolium bromide, Sigma) at $1 \mathrm{mg} / \mathrm{ml} \mathrm{RPMI}$ medium (Seromed, Berlin, Germany). The plates were incubated for three hours at $37^{\circ} \mathrm{C}$ and then centrifuged for seven minutes at $400 \mathrm{~g}$. The medium was replaced with $100 \mu \mathrm{l}$ dimethylsulphoxide (DMSO). The multiwells were shaken on a plate shaker for 10 minutes; they were then read on a Bio-Tek Instrument Microplate Reader (EL 308) using a test wavelength of $570 \mathrm{~nm}$ and a reference one of $630 \mathrm{~nm} .^{28}$

The cells were incubated in an antihormone or anti-growth factor antibody-free medium, for 24 hours in each experimental condition to ensure good plating conditions.

In each experiment the various cell lines were incubated for 72 hours (after the 24 hour plating procedure) in either an anti-hormone or an anti-growth factor antibody-free medium, or both (control), or one supplemented either with $50 \mathrm{ng} / \mathrm{ml}(0.33 \mathrm{nM})$, $500 \mathrm{ng} / \mathrm{ml}(3.3 \mathrm{nM}), 5000 \mathrm{ng} / \mathrm{ml}(33 \mathrm{nM})$, or $10000 \mathrm{ng} / \mathrm{ml}(67 \mathrm{nM})$ of each of the four antibodies under study - that is, the antigastrin (polyclonal A568 rabbit antibody, Dakko, Trappes, France), the anti-EGF (monoclonal MAB126 mouse antibody, Euromedex, Schiltgheim, France), the anti- $\mathrm{E}_{2}$ (monoclonal MAB1233 mouse antibody, Euromedex), and the anti-LHRH (polyclonal AB923 rabbit antibody, Euromedex) antibody.

All the assays were performed in sextuplicate.

\section{STATISTICAL ANALYSES}

The assessments of the cell proliferation (MTT test) are reported as means (SEM) statistically compared by means of the Fisher $F$ test (one way variance analysis). Equality of variance was checked by the Bartlett test. Values of statistical significance represented in the Figures are: ${ }^{\star}=\mathrm{p}<0.05 ; \quad \star \star=\mathrm{p}<0.01$; $\star \star \star=\mathrm{p}<0 \cdot 001$. Correlations between results obtained by different tests were assessed by means of the non-parametric Kendall rank correlation test.

\section{Results}

The Figures show the anti-hormone or antigrowth factor antibody induced effects, or both on the proliferation of the 27 cell lines. In these Figures the mean value of the optical density measured in the control condition at the 96th hour of culture has been arbitrarily represented as equal to $0 \%$. This value of $0 \%$ corresponds to the dark horizontal line that crosses all the graphs in Figs 1-7. The standard errors on the mean are not represented because they were too weak - that is, less than $3 \%$ compared with the mean values. The results relating to the MTT test are thus expressed as a gain or loss in the cell proliferation rate compared with the ' $0 \%$ ' control value: this made an easy comparison possible between all the experimental conditions.

The 27 cell lines represented in Figs 1-7 are ordered according to their increasing sensitivity to the higher $(10000 \mathrm{ng} / \mathrm{ml})$ dose 
Figure 1: The

determination of cell growth

by means of the colorimetric MTT assay under five experimental conditions in the gastrointestinal SW403, AGS, SW1463, and CH1ES (NBL-8) cell lines. Table I gives the description of the cell lines. The five experimental conditions correspond either to the absence (control) or the presence of the anti-gastrin $(G)$, the anti-epidermal growth factor (EGF), the anti-oestradiol $\left(E_{2}\right)$, and the anti-luteinising hormone releasing hormone (LHRH) antibodies. Four concentrations were tested for each antibody - 10000 (black bars), 5000 (shaded bars), 500 (hatched bars), and 50 (open bars) $\mathrm{ng} / \mathrm{ml}$. The mean value of the optical density measured in the control condition at the 96th hour of culture was arbitrarily defined as equal to $0 \%$ (dark horizontal line crossing the graph). The SEM of the control values are not represented because they were too weak and less than $3 \%$ when compared with the mean values. The mean (SEM) values were statistically compared by means of the Fisher $\mathrm{F}$ test (one way variance analysis). The values of statistical significance represented in the Figure are: ${ }^{\star}=p<0.05$ $\star \star=p<0.01$; $\star \star \star=p<0.001$.
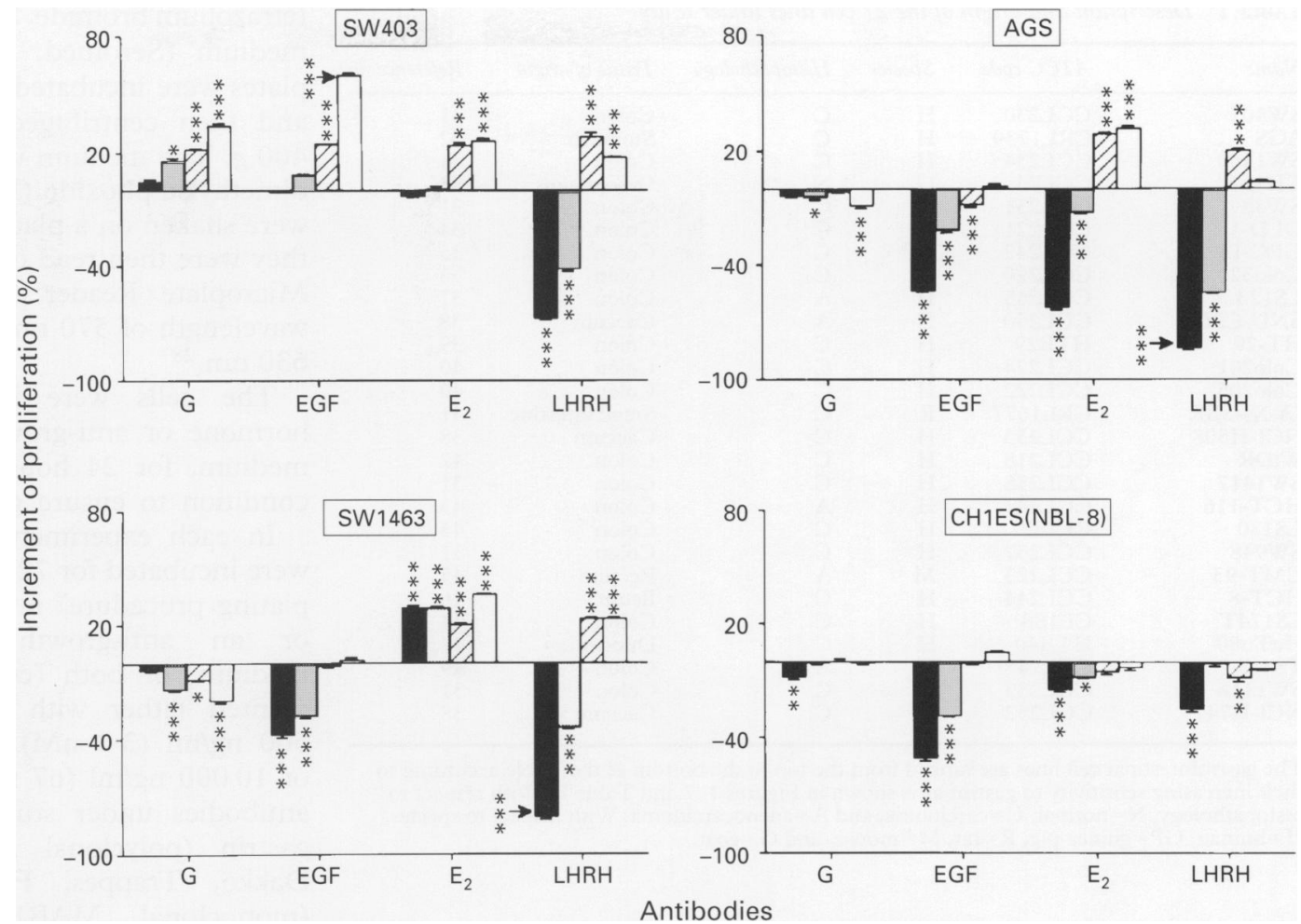

(black bars in Figs 1-7) of the anti-gastrin antibody. Thus, the SW 403 cell line represented in the upper left hand section of the chart in Fig 1 corresponds to a cell line for which a very weak effect was seen in connection with the 10 $000 \mathrm{ng} / \mathrm{ml}$ anti-gastrin antibody. This is in sharp contrast with the cell lines represented in Fig 7.

We have chosen to base our argument on the effect brought about by the maximum dose of the antibody tested here - that is, $10000 \mathrm{ng} / \mathrm{ml}$ - because we consider that this is the dose

that eliminates the higher concentration of the hormone or growth factor under consideration. Thus, we estimate that it is this 10000 $\mathrm{ng} / \mathrm{ml}$ dose of the antibody that provides a more precise definition of the hormone sensitivity profile of the cell line considered.

Nevertheless, Figs 1-7 show that some cell lines (SW403, CoLo201, WiDR) exhibited a low degree of sensitivity, if any, to a given antibody at the highest dose tested, while a significant antibody induced effect was seen on the same cell lines at the lowest doses.
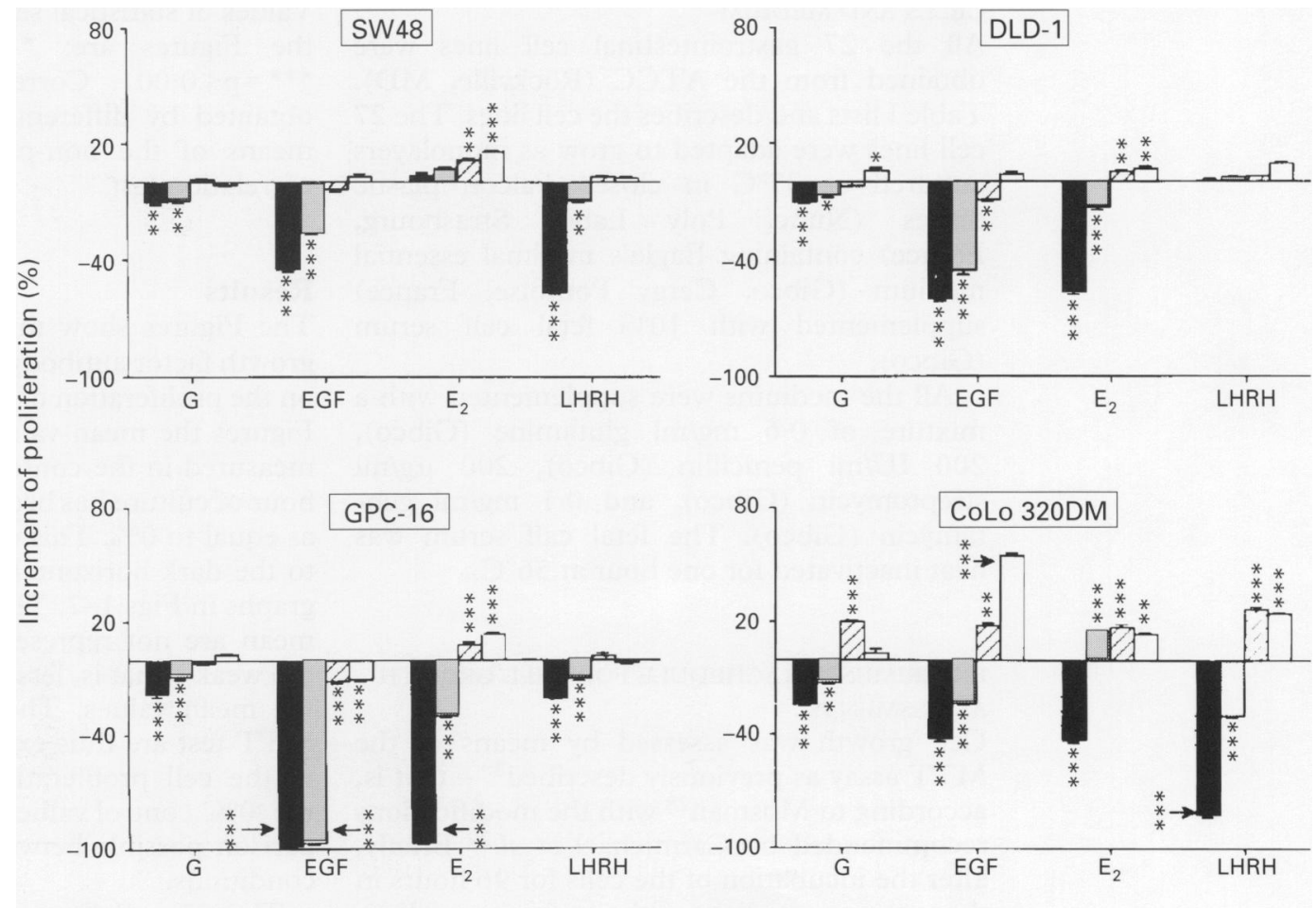

Antibodies

Figure 2: The determination of cell growth by means of the colorimetric MTT assay under five experimental conditions in the gastrointestinal SW48, DLD-1, GPC-16, and CoLo320DM cell lines. The legend is identical to that of Fig 1. 


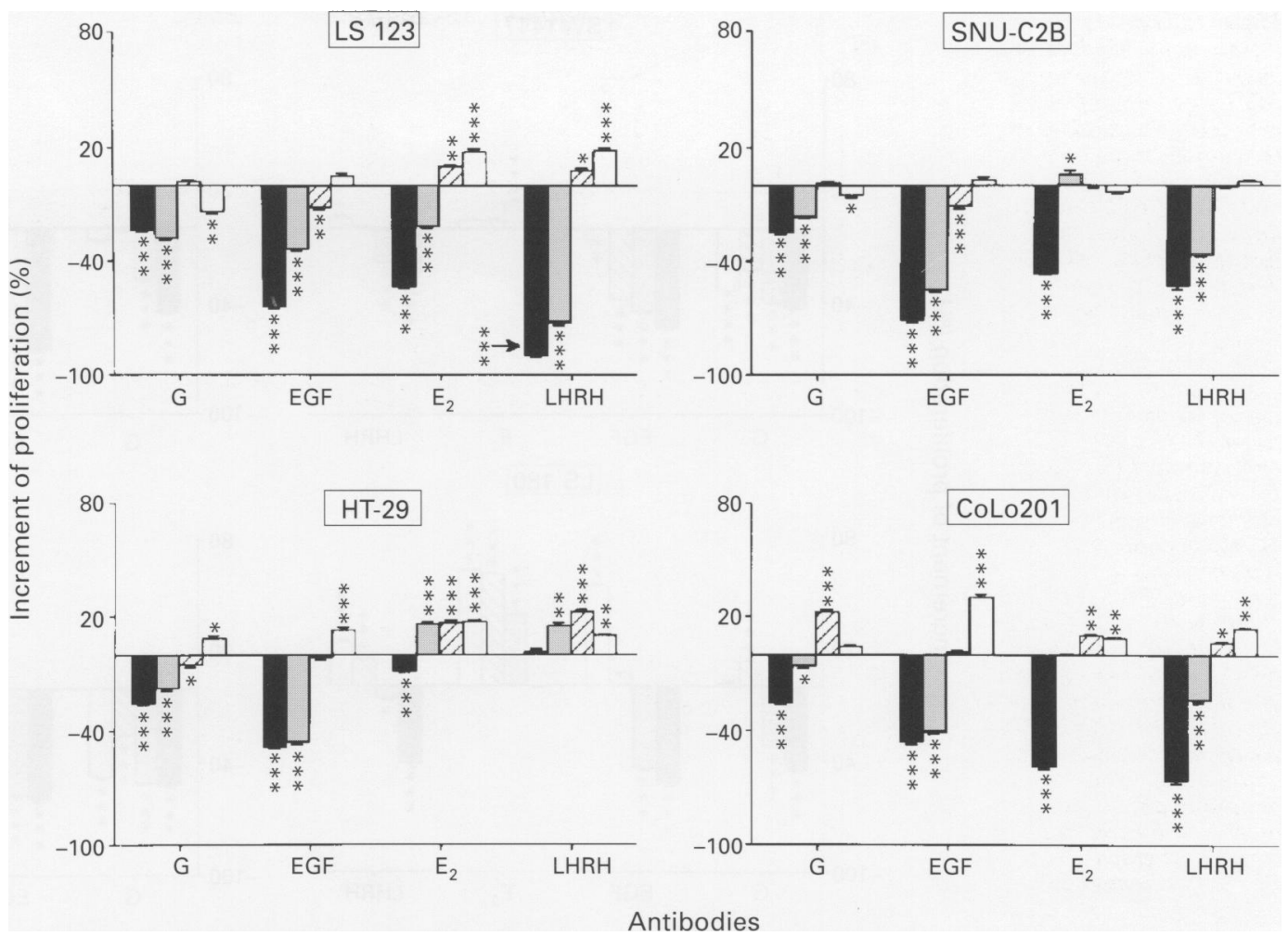

Figure 3: The determination of cell growth by means of the colorimetric MTT assay under five experimental conditions in the gastrointestinal LS123, SNU-C2B, HT-29, and CoLo201 cell lines. The legend is identical to that of Fig 1.

This apparent paradox is considered in the discussion.

Regarding Figs 1-7, it seems impossible to classify the 27 gastrointestinal cell lines under study into subgroups sharing a common hormone sensitivity profile. This is the reason why we decided to study the antibody induced effect at its highest dose to isolate a possible logic behind the hormone sensitivity profile of these 27 cell lines. Table II reports the results where the 27 cell lines are ordered from the least sensitive (top of Table II) to the most (bottom) sensitive cell lines with respect to the anti-gastrin antibody at the $10000 \mathrm{ng} / \mathrm{ml}$ dose as for Figs 1-7. In other words, Table II constitutes a summary of the data presented in

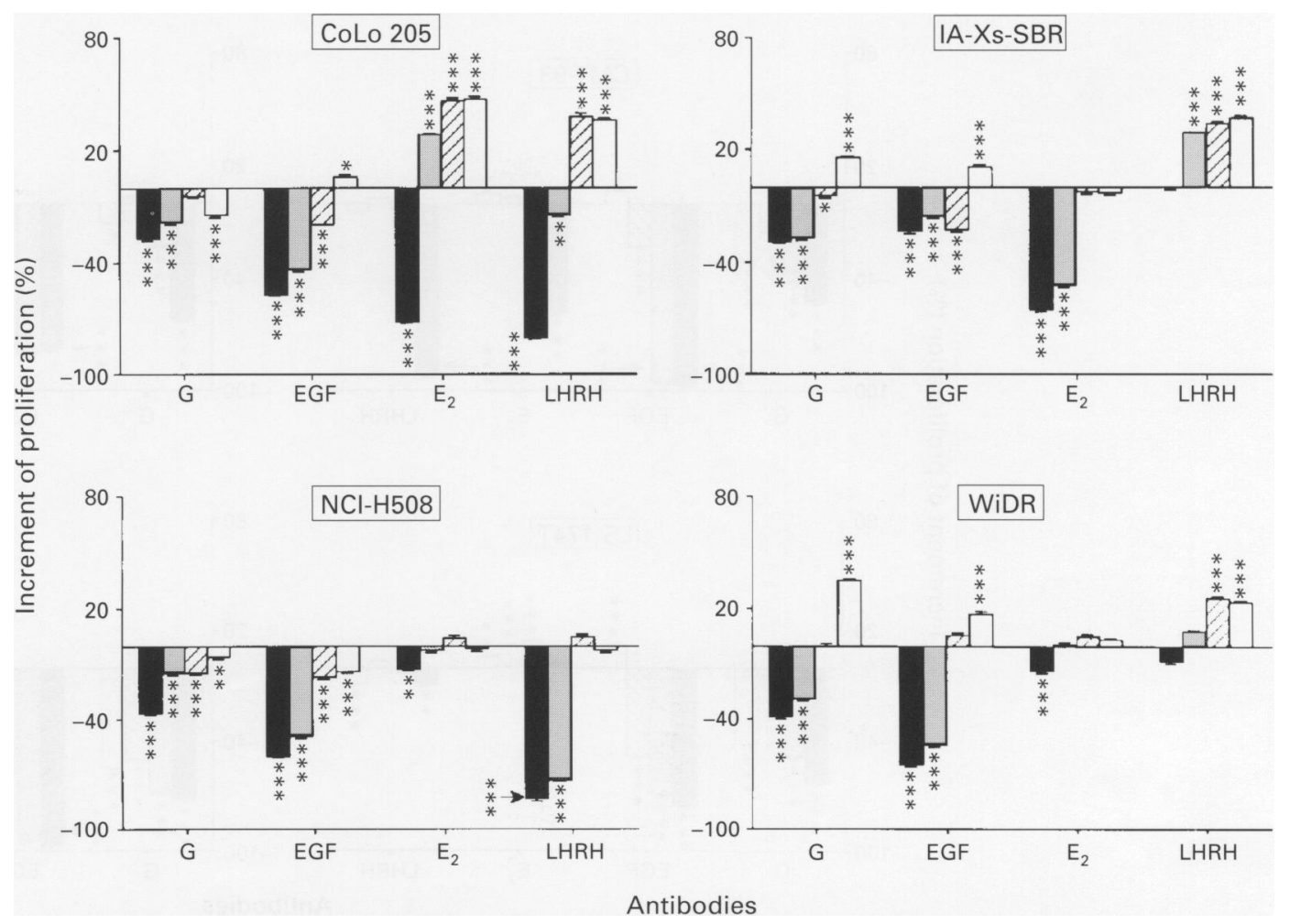

Figure 4: The determination of cell growth by means of the colorimetric MTT assay under five experimental conditions in the gastrointestinal CoLo205, LA-XS-SBR, NCI-H508, and WiDR cell lines. The legend is identical to that of Fig 1. 

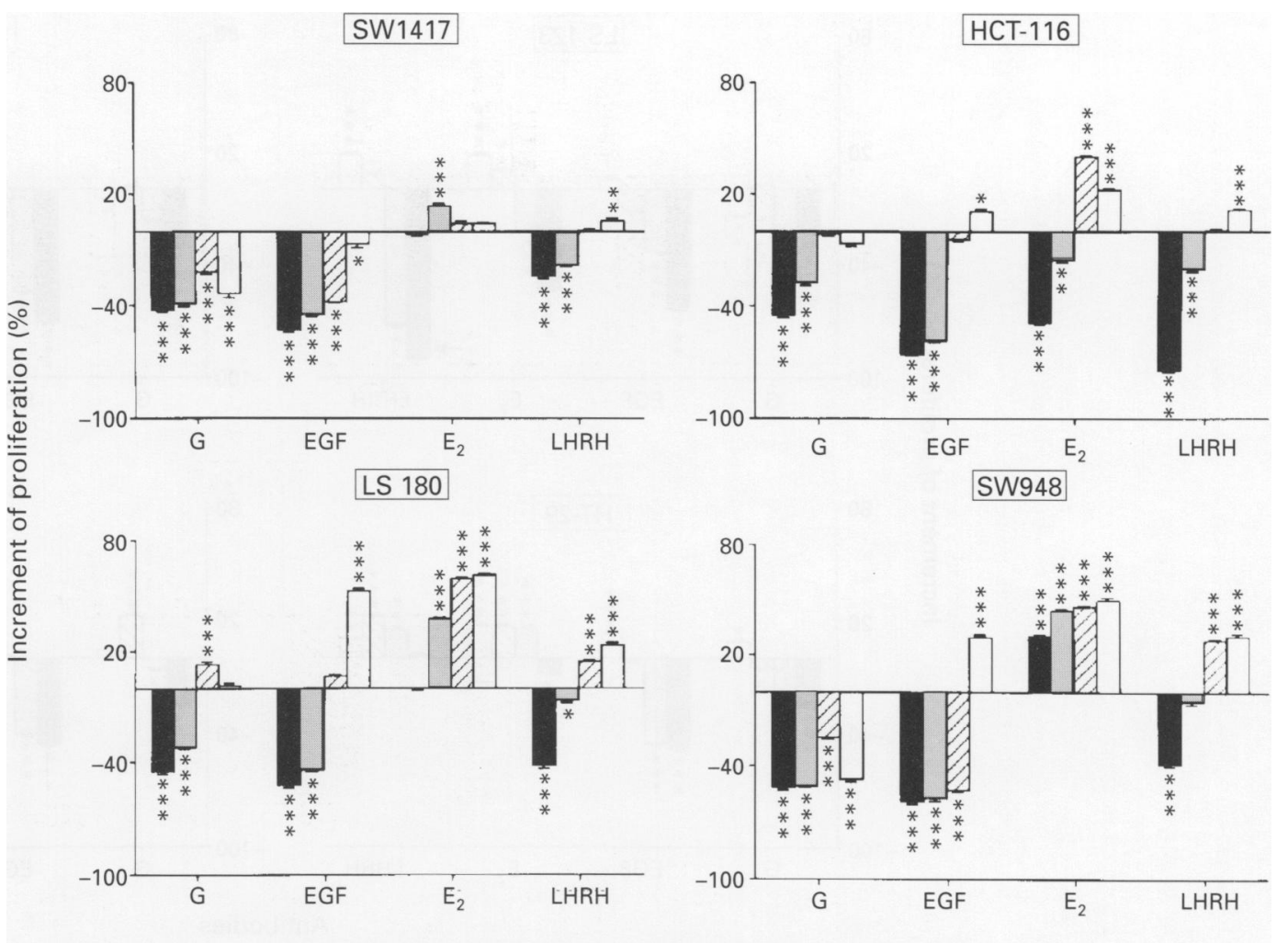

Antibodies

Figure 5: The determination of cell growth by means of the colorimetric MTT assay under five experimental conditions in the gastrointestinal SW1417, HCT-116, LS180, and SW948 cell lines. The legend is identical to that of Fig 1.

Figs 1-7. The symbols used to characterise the anti-hormone or anti-growth factor antibodyinduced effects on cell proliferation are as follows. When the antibody induced effect at the $10000 \mathrm{ng} / \mathrm{ml}$ dose varied by less than $20 \%$ in relation to control, we indicate their effect by 0 . When the effect was between -30 and $-20 \%$ or +20 and $+30 \%$ in relation to

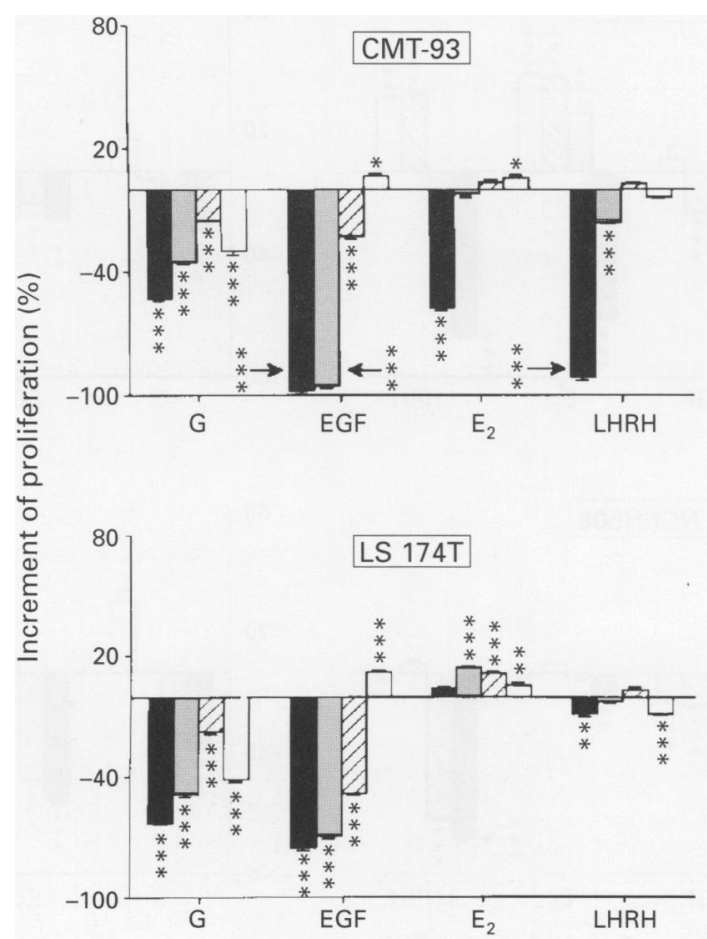

control, we use the symbols - and + . When the effect was between -50 and $-30 \%$ or +30 and $+50 \%$, the symbols are -- and ++ . When the effects were $<-50 \%$ or $>+50 \%$, the symbols are --- and +++ . It seems that in terms of these arbitrarily chosen cut-off values, seven cell lines were gastrin insensitive or only marginally sensitive to gastrin (arbi-

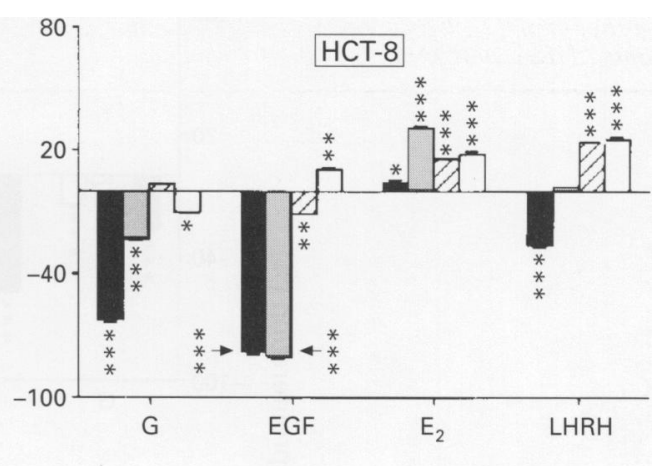

Figure 6: The determination of cell growth by means of the colorimetric MTT assay under five experimental conditions in the gastrointestinal CMT-93, HCT-8, LS174T, and HuTu80 cell lines. The legend is identical to that of Fig 1. 


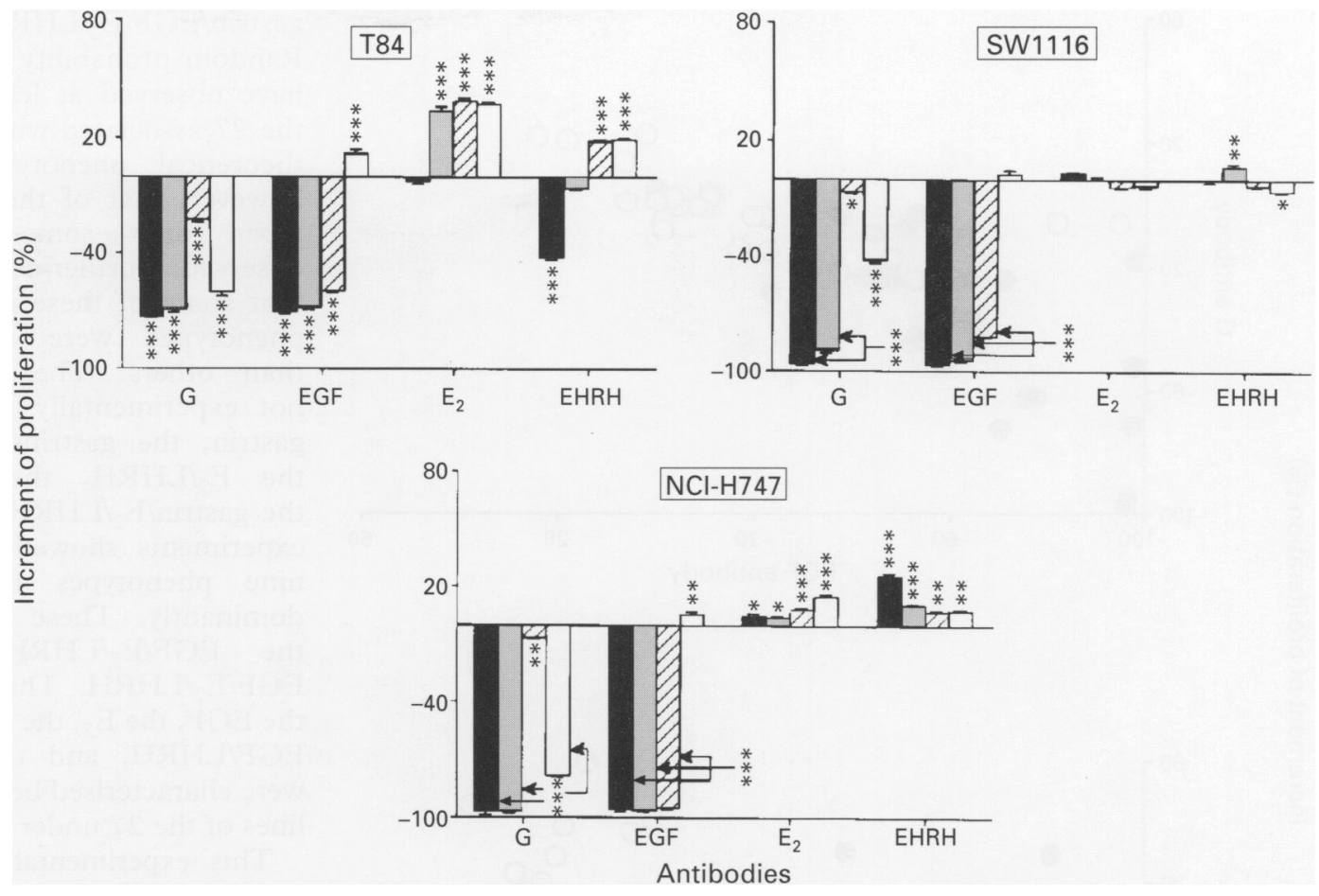

Figure 7: The determination of cell growth by means of the colorimetric MTT assay under five experimental conditions in the gastrointestinal T84, SW1116, and NCI-H747 cell lines. The legend is identical to that of Fig 1.

trary value $=0$ ), seven cell lines were weakly sensitive to gastrin (arbitrary value $=-$ or + ), while the remaining 13 ones were highly gastrin sensitive (arbitrary value $=--,---$, ++ , or +++ ). In sharp contrast with what was seen with respect to gastrin, 25 of 27 cell lines were highly sensitive to EGF (Table II). As for the anti- $\mathrm{E}_{2}$ and anti-LHRH antibodies, there were 12 and 16 cell lines respectively,

TABLE II Summary of the data relating to the influence on the proliferation of the 27 gastrointestinal cell lines under study of the anti-G, the anti-E $E_{2}$, the anti-EGF, and the anti-LHRH antibody at the $10000 \mathrm{ng} / \mathrm{ml}$ dose

\begin{tabular}{|c|c|c|c|c|c|}
\hline \multirow[b]{2}{*}{ Name } & \multicolumn{4}{|c|}{ Anti-X antibody induced effect } & \multirow[b]{2}{*}{ Resulting phenotype } \\
\hline & $G$ & $E G F$ & $E_{2}$ & $L H R H$ & \\
\hline SW403 & 0 & 0 & 0 & --- & LHRH \\
\hline AGS & 0 & --- & --- & --- & $\mathrm{EGF} / \mathrm{E}_{2} / \mathrm{LHRH}$ \\
\hline SW 1463 & 0 & -- & + & --- & EGF/LHRH \\
\hline CH1ES (NBL-8) & 0 & -- & 0 & - & EGF \\
\hline SW48 & 0 & -- & 0 & --- & EGF/LHRH \\
\hline DLD-1 & 0 & --- & --- & 0 & $\mathrm{EGF} / \mathrm{E}_{2}$ \\
\hline GPC-16 & 0 & --- & --- & - & $\mathrm{EGF} / \mathrm{E}_{2}^{2}$ \\
\hline Colo320 & - & -- & -- & --- & $\mathrm{EGF} / \mathrm{E}_{2} / \mathrm{LHRH}$ \\
\hline $\mathrm{LS} 123$ & - & --- & --- & --- & EGF/E $/$ LHRH \\
\hline SNU-C2B & - & --- & $-\cdots$ & --- & EGF/E $/$ LHRH \\
\hline НT-29 & - & -- & 0 & 0 & EGF \\
\hline Colo201 & - & -- & --- & --- & $\mathrm{EGF} / \mathrm{E}_{2} / \mathrm{LHRH}$ \\
\hline Colo205 & - & --- & --- & --- & $\mathrm{EGF} / \mathrm{E}_{2} / \mathrm{LHRH}$ \\
\hline IX-Xs-SBR & - & - & --- & 0 & $\mathrm{E}_{2}$ \\
\hline NCI-H508 & --- & --- & 0 & + & $\mathrm{G} / \mathrm{EGF}$ \\
\hline WiDR & -- & --- & 0 & 0 & G/EGF \\
\hline SW 1417 & -- & --- & 0 & - & G/EGF \\
\hline НCT-116 & -- & --- & -- & --- & $\mathrm{G} / \mathrm{EGF} / \mathrm{E}_{2} / \mathrm{LHRH}$ \\
\hline LS 180 & -- & -- & 0 & -- & G/EGF/LHRH \\
\hline SW948 & --- & --- & ++ & -- & $\mathrm{G} / \mathrm{EGF} / \mathrm{E}_{2} / \mathrm{LHRH}$ \\
\hline СMT-93 & --- & --- & --- & --- & $\mathrm{G} / \mathrm{EGF} / \mathrm{E}_{2} / \mathrm{LHRH}$ \\
\hline НCT-8 & -- & --- & 0 & - & G/EGF \\
\hline LS174T & --- & --- & 0 & 0 & G/EGF \\
\hline HuTu80 & --- & --- & --- & --- & $\mathrm{G} / \mathrm{EGF} / \mathrm{E}_{2} / \mathrm{LHRH}$ \\
\hline $\mathrm{T} 84$ & --- & --- & 0 & -- & G/EGF/LHRH \\
\hline SW1116 & --- & -- & 0 & 0 & $\mathrm{G} / \mathrm{EGF}$ \\
\hline NCI-H747 & -- & --- & 0 & --- & G/EGF/LHRH \\
\hline
\end{tabular}

We have divided the antibody into four groups on the basis of the increase in their effect on NSCLC cell proliferation. When the antibody induced effect varied by less than $20 \%$ in relation to control, we indicate the effect by 0 . When the effect is between -30 and $-20 \%$ or +20 and $+30 \%$ in relation to control, we use the symbols - and + . When the effect is between -50 and $-30 \%$ or +30 and $+50 \%$, the symbols are -- and ++ . When it is $<-50 \%$ or $>+50 \%$, the symbols are --- and +++ . which were highly sensitive to these hormones.

Table II shows that the distribution over the four antibodies of the arbitrary values defined above seems to be random. In fact, as four distinct antibodies were used in this study, there are 16 combinations that make a hormone sensitive phenotype of the cell line possible. To caricature the antibody induced effects and to try to find a law governing their action at cell proliferation level, we only considered their effects in terms of absolute values - that is, independently of the fact that such an effect stimulated or inhibited cell proliferation. On the other hand, we only retained those effects whose arbitrary values equalled the,,-----++ , and +++ cut off values recorded at the $10000 \mathrm{ng} / \mathrm{ml}$ dose. This was done because it was at this $10000 \mathrm{ng} / \mathrm{ml}$ dose that the greatest biological hormone or growth factor activity was inhibited, and as a consequence it was at this dose that the most accurate mirror image was obtained of what the influence of the hormone or the growth factor at its physiological dose might have been.

Sixteen theoretical phenotypes of hormone sensitivity can be defined in terms of the four hormones or growth factors under study. These phenotypes are defined as follows. The cell line that exhibited no response to the four antibodies at their highest dose was labelled HI - that is, hormone insensitive (phenotype no 1 ). The cell line that was sensitive to only one hormone or growth factor was defined as either gastrin, EGF, $\mathrm{E}_{2}$, or LHRH sensitive (phenotypes no 2-5). The cell line was sensitive to two of the four antibodies tested. Six combinations exist - that is, sensitive to gastrin and EGF (or to EGF and gastrin, phenotype no 6 defined as gastrin/EGF), 

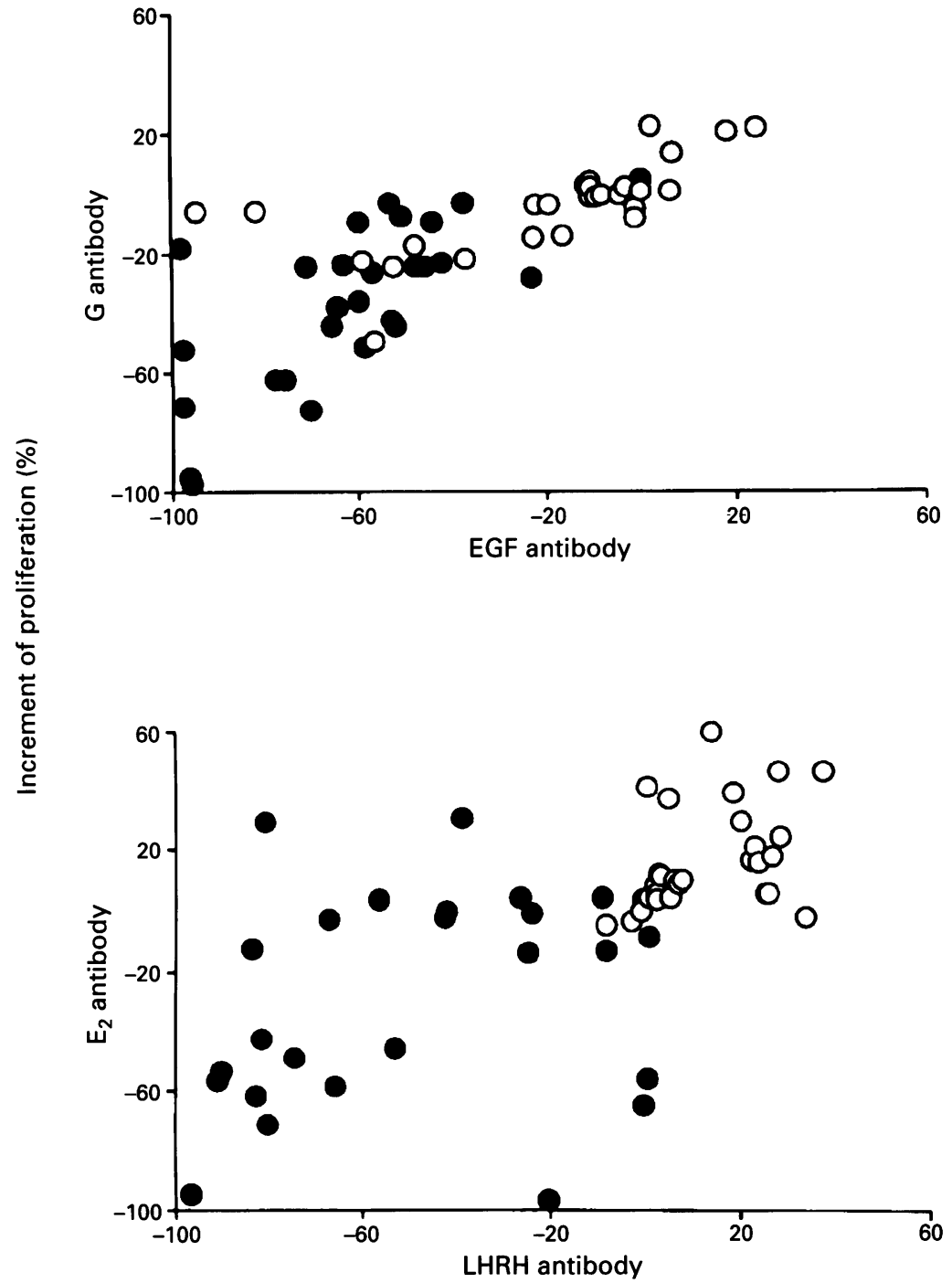

Increment of proliferation (\%)

Figure 8: Relation between the anti-gastrin $(G)$ and anti-EGF antibody induced effects (top) and between the anti- $E_{2}$ and anti-LHRH antibody induced ones (bottom). The black dots represent the $10000 \mathrm{ng} / \mathrm{ml}$ dose and the open dots represent the $500 \mathrm{ng} / \mathrm{ml}$ one. The values relating to the increment of proliferation come from Figs 1-7.

gastrin and $\mathrm{E}_{2}$ (phenotype no 7), gastrin and LHRH (phenotype no 8), EGF and $\mathrm{E}_{2}$ (phenotype no 9), EGF and LHRH (phenotype no 10), and $E_{2}$ and LHRH (phenotype no 11). The cell line was sensitive to three of the four antibodies. Four phenotypes exist that is, gastrin/EGF/ $\mathrm{E}_{2}$ (phenotype no 12), gastrin/EGF/LHRH (phenotype no 13), $\mathrm{EGF} / \mathrm{E}_{2} / \mathrm{LHRH}$ (phenotype no 14), and gastrin/E $\mathrm{E}_{2} /$ LHRH (phenotype no 15). Lastly, only one combination defined the phenotype describing the fact that the cell line was sensitive to the four hormones or growth factors. This phenotype was defined as
gastrin/EGF/ $\mathrm{E}_{2} / \mathrm{LHRH}$ (phenotype no 16). Random probability dictates that we should have observed at least one cell line out of the 27 associated with one of each of the 16 theoretical phenotypes. Table II shows, however, that of the 16 theoretical phenotypes only some were experimentally observed. Furthermore, Table II also shows that some of these experimentally observed phenotypes were seen more frequently than others. The theoretical phenotypes not experimentally seen were the $\mathrm{HI}$, the gastrin, the gastrin/ $\mathrm{E}_{2}$, the gastrin/LHRH, the $E_{2} / \mathrm{LHRH}$, the gastrin/EGF/ $\mathrm{E}_{2}$, and the gastrin/ $\mathrm{E}_{2} / \mathrm{LHRH}$. In sharp contrast, the experiments showed that of the remaining nine phenotypes three were seen predominantly. These were the gastrin/EGF, the $\mathrm{EGF} / \mathrm{E}_{2} / \mathrm{LHRH}$, and the gastrin/ $\mathrm{EGF} / \mathrm{E}_{2} / \mathrm{LHRH}$. The other six phenotypes, the EGF, the $\mathrm{E}_{2}$, the $\mathrm{LHRH}$, the $\mathrm{EGF} / \mathrm{E}_{2}$, the EGF/LHRH, and the gastrin/EGF/LHRH, were characterised between one and three cell lines of the 27 under study.

This experimental absence of some theoretical phenotypes and the presence of some other predominant ones led us to try to find a possible statistically significant relation between the combined effect of some of the hormones or growth factors under study. Figure 8 and Table III shows the results.

Table III shows that the anti-gastrin antibody induced effect on the proliferation of the 27 cell lines at the $10000 \mathrm{ng} / \mathrm{ml}$ and $500 \mathrm{ng} / \mathrm{ml}$ doses was highly correlated with those of the anti-EGF antibody. A statistically significant effect was also seen with the $5000 \mathrm{ng} / \mathrm{ml}$ dose but not with the $50 \mathrm{ng} / \mathrm{ml}$ one (data not shown). In the same way, the anti- $\mathrm{E}_{2}$ antibody induced effect on the proliferation of the 27 cell lines correlated significantly with that of the anti-LHRH effect. This effect was more noticeable at the 5000 (data not shown) and $500 \mathrm{ng} / \mathrm{ml}$ doses than at the $10000 \mathrm{ng} / \mathrm{ml}$ one. No statistically significant relation was seen at the $50 \mathrm{ng} / \mathrm{ml}$ dose (data not shown).

Table III shows that, in sharp contrast with what is described before, no statistically significant relation was seen between the other combinations - that is, the anti-gastrin antibody compared with the anti- $\mathrm{E}_{2}$ or anti-LHRH ones on the one hand and the anti-EGF antibody compared with the anti- $\mathrm{E}_{2}$ and anti-LHRH ones.

Figure 8 illustrates the pattern of such a significant relation between the anti-gastrin and anti-EGF antibodies and between the anti- $\mathrm{E}_{2}$ and anti-LHRH antibodies. The black dots correspond to the antibody induced effects at the $10000 \mathrm{ng} / \mathrm{ml}$ dose while the open

TABLE III Statistical p value from Kendall rank correlation test performed on the proliferation values obtained after adding the different anti-hormone or anti-growth factor antibody in the culture medium

\begin{tabular}{|c|c|c|c|c|c|c|}
\hline & \multicolumn{3}{|c|}{ Dose $(10000 \mathrm{ng} / \mathrm{ml})$} & \multicolumn{3}{|c|}{ Dose $(500 \mathrm{ng} / \mathrm{ml})$} \\
\hline & $\begin{array}{l}\text { Anti-EGF } \\
\text { antibody }\end{array}$ & $\begin{array}{l}\text { Anti-E } E_{2} \\
\text { antibody }\end{array}$ & $\begin{array}{l}\text { Anti-LHRH } \\
\text { antibody }\end{array}$ & $\begin{array}{l}\text { Anti-EGF } \\
\text { antibody }\end{array}$ & $\begin{array}{l}\text { Anti-E } E_{2} \\
\text { antibody }\end{array}$ & $\begin{array}{l}\text { Anti-LHRH } \\
\text { antibody }\end{array}$ \\
\hline $\begin{array}{l}\text { Anti-G antibody } \\
\text { Anti-EGF antibody } \\
\text { Anti-E } E_{2} \text { antibody }\end{array}$ & $\begin{array}{l}p=0.0002 \\
-\end{array}$ & $\begin{array}{l}p=0.0975 \\
p=0.8128 \\
-\end{array}$ & $\begin{array}{l}p=0.2740 \\
p=0.6346 \\
p=0.0518\end{array}$ & $\begin{array}{l}\mathrm{p}<0.0001 \\
- \\
-\end{array}$ & $\begin{array}{l}p=0 \cdot 8780 \\
p=0.3840 \\
-\end{array}$ & $\begin{array}{l}p=0.4962 \\
p=0.2484 \\
p=0.0032\end{array}$ \\
\hline
\end{tabular}


dots correspond to the effects recorded at the $500 \mathrm{ng} / \mathrm{ml}$ dose. It seems that such relations are linear and positive and are more pronounced between the anti-gastrin and anti-EGF antibodies than between the anti- $\mathrm{E}_{2}$ and anti-LHRH ones.

\section{Discussion}

In a study (unpublished data) we describe the influence of various anti-hormone or antigrowth factor antibodies on the proliferation of two human neoplastic colorectal cell lines, the LoVo and HCT-15 cells. The data show that of the 19 antibodies tested, 10 modified the in vitro proliferation of these two cell lines very significantly. These 10 antibodies were the anti-insulin like growth factor I, the anti-transforming growth factor alpha, the anti-basic fibroblast growth factor, the anticarcinoembryonic antigen, the anti-prolactin, the anti-platelet derived growth factor, the anti-gastrin, the anti-EGF, the anti- $\mathrm{E}_{2}$, and the anti-LHRH antibodies. As for the remaining nine antibodies in this study (the antitransforming growth factor beta, the antitumour necrosis factors alpha and beta, the anti-bombesin, the anti-nerve growth factor, the anti-substance $P$, the anti-secretin, the anti-somatostatin, and the anti-vasoactive intestinal peptide antibodies), we were not able to show any really significant influence on LoVo and HCT-15 cell proliferation.

To test the clinical relevance of these data we decided to continue our experiment with an investigation into the effect on a large series of gastrointestinal cell lines of anti-hormone or anti-growth factor antibodies known to have a considerable influence on the proliferation of the LoVo and the HCT-15 cell lines. This is the aim of this study, which characterises the influence of the anti-gastrin, anti-EGF, anti- $\mathrm{E}_{2}$, and anti-LHRH antibodies on the proliferation of 27 gastrointestinal cell lines.

The methodology used here is unusual. Indeed, it was the anti-hormone or anti-growth factor antibody rather than the hormone or growth factor itself that was used to characterise the hormone sensitivity profile of the gastrointestinal cell line under consideration. We used this methodology because our laboratory has been able to observe some very considerable interference in the field of cell proliferation between the effect of the hormone added exogeneously to the culture medium and that of the hormone existing endogeneously in the same medium. This finding, made over a number of years, is based on a very large number of experimental models. Our present argument is wholly based on the opinion that the addition of the antibody to the culture medium will inhibit the biological activity of the hormone or the growth factor targeted and that the most effective inhibition of this biological activity is obtained at the highest concentration used here, namely $10000 \mathrm{ng} / \mathrm{ml}$. In other words, we believe that a concentration of $10000 \mathrm{ng} / \mathrm{ml}$ provides the best mirror image of what the influence of the hormone or growth factor would have been at an equivalent concentration. We could not test any higher antibody concentrations because of the cost of the experiments.

It should also be emphasised that we preferred to use the anti-hormone or anti-growth factor antibody rather than the hormone or growth factor itself because more information becomes available in this way. Indeed, a positive effect of hormones or growth factors added to the medium is evidence of sensitivity of the tumour cells to the hormone or growth factor tried, but it does not provide any information on the possible action of the same hormone or growth factor on cultures growing in unsupplemented medium. The influence of neutralising antibodies on growth of the culture is proof that the cell lines were already stimulated by the corresponding hormone or growth factor, either present in the fetal calf serum used in the medium, or secreted by an autocrine or paracrine mechanism, or both by the tumour cells themselves.

It should also be emphasised that this study assessed the proliferation rate by means of the recently criticised ${ }^{50-52}$ colorimetric assay. ${ }^{28-30}$ We maintain that we really did measure the cell proliferation rate by means of the MTT test because we carried out the appropriate controls. Indeed, in three distinct studies (reference 12 and two manuscripts submitted for publication) we compared the data obtained by means of two different tests with those obtained by means of the MTT test. These two tests entailed the tritiated-thymidine incorporation into the genomic material ${ }^{53}$ and direct cell nuclei counting. ${ }^{1254}$ The results showed identical results with the three tests with respect to the inhibitory influence on the proliferation of the LoVo and HCT-15 cell lines of the anti-carcinoembryonic, the anti-EGF, and the anti-LHRH antibodies.

These results show that it was the EGF $(93 \%)$ and not the gastrin $(48 \%)$ that significantly influenced the highest number of gastrointestinal cell lines under study. Also the $\mathrm{E}_{2}$ and LHRH significantly influenced the proliferation of about half of the 27 cell lines in terms of cell proliferation. None of the gastrointestinal cell lines was simultaneously insensitive to the four hormones or growth factors. These data are thus corroborated by those of Frucht $e t a l,{ }^{27}$ who report that a total of 27 receptors out of a possible $120(23 \%)$ occurred on 10 gastrointestinal cell lines, a fact which shows in our opinion that the presence of receptors for gastrointestinal hormones and neurotransmitters in human colon cancer cell lines is not an uncommon occurrence. Both our data and those of Frucht et al ${ }^{27}$ clearly show that the gastrin does not play an important part with respect to the regulation of gastrointestinal cell line proliferation.

This study shows that there were 16 theoretical hormone sensitive phenotypes that could exist given the fact that four hormones or growth factors were used; of these only nine were present, and of these nine, three predominated. These facts strongly suggest that coregulating phenomena with respect to gastrointestinal cell proliferation occur 
between the four hormones or growth factors under study. By way of an example, none of the 27 gastrointestinal cell lines under study seemed to be sensitive to the gastrin only, as was also the case with the $\mathrm{E}_{2}+\mathrm{LHRH}$. Moreover, the gastrin/ $\mathrm{E}_{2}$, the gastrin/LHRH, and the gastrin/ $\mathrm{E}_{2} / \mathrm{LHRH}$ do not exist. Everything suggests that the gastrin and $\mathrm{E}_{2}+\mathrm{LHRH}$ would act as independent regulators of the in vitro gastrointestinal cell proliferation. In addition to these two independent regulators, the EGF seems to constitute a third regulator that is not independent of the other two, but more the dominant partner. However, the gastrin/EGF/ $\mathrm{E}_{2}$ phenotype does not exist. It thus seems impossible to see a noticeable and concomitant gastrin and $\mathrm{E}_{2}$ induced stimulation of the gastrointestinal cell proliferation. These two hormones seem to be mutually exclusive with respect to their action on the gastrointestinal cell proliferation. This feature might be related to up and down regulation phenomena exerted by the gastrin and $E_{2}$ at the level of their secretion or receptor expression, or both. ${ }^{55} 56$

While the results show that the effects of certain hormones or growth factors can be correlated with the proliferation of the neoplastic gastrointestinal cells, they also raise the problem of the possible effectiveness of mono-hormonotherapy on this type of cancer. In fact, antagonising the biological activity of a hormone by the use of an antagonist is not wholly inconceivable. This is true for tamoxifen and oestradiol in the case of breast cancers. These results strongly suggest that, in the case of the projected treatment of colorectal cancer by hormonotherapy, there would be an immediate need for polyhormonotherapy including at least gastrin, oestradiol, and LHRH antagonists because otherwise the hormone whose effect had not been antagonised at proliferation level might replace the other one. In the same way, it seems that the use of a gastrin antagonist alone would not be enough to inhibit the proliferation of neoplastic gastrointestinal cells sensitive to it as the EGF is more than likely to take over. Experiments are being carried out in the laboratory to investigate the effect of various combinations between the anti-gastrin, the anti- $\mathrm{E}_{2}$, and the anti-LHRH antibodies on the gastrointestinal cell line proliferation.

The results described concern four hormones or growth factors, of which three are well known for influencing gastrointestinal cell proliferation. These are the gastrin, ${ }^{1-12}$ the $\mathrm{E}_{2},{ }^{19-21}$ and the EGF. ${ }^{22}{ }^{23}$ To our knowledge we were the first to show that the LHRH can also significantly influence the proliferation of colorectal cells, ${ }^{21}$ a feature that is confirmed by this study on a large series of gastrointestinal cell lines.

As Table I shows, the $\mathbf{2 7}$ gastrointestinal cell lines did not exhibit the same histopathological characteristics or origin. We tested whether these differences in histopathological (colorectal compared with non-colorectal, carcinoma compared with adenocarcinoma, etc) characteristics and origin (human compared with non-human) could influence the results. No statistically significant results were obtained (data not shown).

The results show that most of the antihormone or anti-growth factor antibodies induced a dose dependent effect on the gastrointestinal cell proliferation. This was the case with respect to the anti-EGF antibody on the GPC-16 cell line (Fig 2) and to the anti-LHRH antibody on the NCI-H508 one (Fig 4). In contrast, some intermediate situations were also seen. For example, this was the case with respect to the SW403 cell line, where the anti-gastrin, the anti-EGF, and the anti- $\mathrm{E}_{2}$ antibodies induced an increase and not a decrease in cell proliferation (Fig 1). This was also seen with respect to the effect of the anti-E $E_{2}$ antibody on SW1463 (Fig 1) and LS180 (Fig 5) cell proliferation. It was also seen that a given antibody induced a potent inhibition of cell proliferation at a high dose but a stimulation of the same cell proliferation at a lower one. This was the case with the effects of the anti-LHRH antibody on SW403 cell proliferation (Fig 1), of the antiEGF antibody on CoLo320DM proliferation (Fig 2), and of the anti- $\mathrm{E}_{2}$ antibody on the CoLo205 (Fig 4).

We think that such antibody induced rebound effects might be partly explained by the fact that the hormones or the growth factor may exert a dual influence on the proliferation of some cancers. This dual influence corresponds to a stimulating influence on cell proliferation accompanied by an increase in mitoses, and to an inhibitory one accompanied by an increase in apoptosis. Such dual hormone or growth factor induced effects on cell proliferation are described in several experimental models related to the liver, ${ }^{57}$ the MXT mouse mammary carcinoma, ${ }^{58}$ the uterus, ${ }^{59}$ and the prostate. ${ }^{60}$

In conclusion, we believe that when the antibody brings about a significant decrease in cell proliferation when tested at the highest concentration, this corresponds to the elimination of the mitogeneous activity of the hormone or the growth factor. In contrast, we believe that when a lower concentration of this antibody brings about an increase in cell proliferation, this corresponds to the elimination of a part of the hormone or growth factor induced apoptosis related cell death effect. As the cell lines proliferate very rapidly in vitro (and never regress spontaneously), it is logical for us to have seen that while the mitogeneous biological activity of a hormone or growth factor is associated with large amounts of the antibody, the biological activity connected with the apoptosis entails smaller amounts. We are in the process of testing this hypothesis by means of biochemical (endonuclease activation) and electron microscopy (search for apoptotic bodies) experiments.

These data characterised the influence of the anti-gastrin, the anti-EGF, the anti- $\mathrm{E}_{2}$, and the anti-LHRH antibodies on the proliferation of 27 gastrointestinal cell lines and show that it was the anti-EGF neutralising antibody that had the greatest (93\%) and the 
most noticeable influence on the gastrointestinal cell line proliferation. In contrast, the anti- $\mathrm{E}_{2}$, the anti-gastrin, and the antiLHRH neutralising antibodies had a real influence on only about half of the gastrointestinal cell proliferation. Thus, the gastrin was not the major regulator of the gastrointestinal cell line proliferation. The antigastrin and anti-EGF antibody induced effects on the 27 gastrointestinal cell line proliferation were significantly correlated, as was also the case for the anti- $\mathrm{E}_{2}$ and antiLHRH antibody induced effects. Lastly, none of the gastrointestinal cell lines was totally hormone insensitive and in view of the fact that four anti-hormone or anti-growth factor antibodies were used in this study, 16 theoretical hormone sensitive phenotypes were possible but only nine were experimentally seen. Of these nine phenotypes, three were predominant. These were defined as the gastrin/EGF, the $\mathrm{EGF} / \mathrm{E}_{2} / \mathrm{LHRH}$, and the gastrin/EGF/E $/ \mathrm{E}_{2} / \mathrm{LHRH}$ and showed that the gastrointestinal cell lines exhibited an equal degree of sensitivity to gastrin $+E G F$, $\mathrm{EGF}+\mathrm{E}_{2}+\mathrm{LHRH}$, and to gastrin $+\mathrm{EGF}+$ $\mathrm{E}_{2}+\mathrm{LHRH}$

Additional experiments are currently under way in the laboratory to characterise the biochemical transduction pathway used by these various anti-hormone or anti-growth factor antibodies.

FD is the holder of a grant from the CIFRE, France; IC is the holder of a grant from the FNRS, Belgium; RK is a Research Associate with the FNRS, Belgium.

1 Winsett OE, Townsend CM Jr, Glass EJ, Thompson JC. Gastrin stimulates growth of colon cancer. Surgery 1986; 99: 302-7.

2 Singh P, Walker JP, Townsend CM Jr, Thompson JC. Role of gastrin and gastrin receptors on the growth of a transplantable mouse colon carcinoma (MC-26) in BALBc mice. Cancer Res 1986; 46: 1612-6.

3 Morris DL, Watson SA, Durrant LG, Harrison JD. Hormonal control of gastric and colorectal cancer in man. Gut 1989; 30: 425-9.

4 Watson SA, Durrant LG, Morris DL. Gastrin: growth enhancing effects on human gastric and colonic tumour cells. Br f Cancer 1989; 59: 554-8.

5 Brown J, Gallagher ND. A specific gastrin receptor site in the rat stomach. Biochem Biophys Acta 1978; 538: 42-9.

6 Takeuchi K, Speir GR, Johnson LR. Mucosal gastrin receptor. I. Assay standardization and fulfilment of receptor critor. I. Assay standardization and fulfilme

7 Soll AH, Amirian DA, Thomas LP, Reedy J, Elashoff JD. Gastrin receptors on isolated canine parietal cells. $\mathcal{f}$ Clin Invest 1984; 73: 1734-47.

8 Weinstock J, Baldwin GS. Binding of gastrin 17 to human gastric carcinoma cell lines. Cancer Res 1988; 48: 932-7.

9 Watson SA, Durrant LG, Elston P, Morris DL. Inhibitory effects of the gastrin receptor antagonist (L-365,260) on gastrointestinal tumor cells. Cancer 1991; 68: 1255-60.

10 Hoosein NM, Kiener PA, Curry RC, Brattain MG. Evidence for autocrine growth stimulation of cultured Evidence for autocrine growth stimulation of cultured
colon tumor cells by a gastrin/cholecystokinin-like colon tumor cells by a gastrin/ch
peptide. Exp Cell Res 1990; 186: 15-21.

11 peptide. Exp Cell Res 1990; 186: 15-21. DL. Intracellular gastrin in human gastrointestinal tumor DL. Intracellular gastrin in human gastrointes
cells. F Natl Cancer Inst 1991; 83: 866-71.

12 Darro F, Kruczynski A, Etievant C, Martinez J, Pasteels JL, Kiss $\mathbf{R}$. Characterization of the differentiation of human colorectal cancer cell lines by means of Voronoi diagrams. Cytometry 1994; 14: 783-92.

13 Lahm H, Suardet L, Laurent PL, Fischer JR, Ceyhan A, Givel JC, et al. Growth regulation and co-stimulation of human colorectal cancer cell lines by insulin-like growth factor I, II and transforming growth factor alpha. $\mathrm{Br} f$ Cancer 1992; 65: 341-6.

14 Murthy U, Anzano MA, Greig RG. Expression of TGFalpha/EGF and TGFbeta receptors in human colon carcinoma cell lines. Int $\mathcal{f}$ Cancer 1989; 44: 110-5.

15 Tanaka S, Imanishi KI, Yoshihara M, Haruma K, Sumii K, Kajiyama G, et al. Immunoreactive transforming growth factor alpha is commonly present in colorectal neoplasia. Am $\mathcal{f}$ Pathol 1991; 139: 123-9.

16 Coffey RJ, Goustin AS, Soderquist AM, Shipley GD, Wolfshohl J, Carpenter G, et al. Transforming growth fac- tor alpha and beta expression in human colon cancer lines: implications for an autocrine model. Cancer Res 1987; 47: 4590-4.

17 Tricolli JV, Rall LB, Karakousis CP, Herrera L, Petrelli NJ, Bell GI, et al. Enhanced levels of insulin-like growth factor messenger RNA in human colon carcinoma and factor messenger RNA in human colon carcin

18 New BA, Yeoman LC. Identification of basic fibroblast growth factor sensitivity and receptor and ligand expression in human colon tumor cell lines. $\mathcal{F}$ Cell Physiol 1992; 150: $320-6$.

19 Murakami H, Masui H. Hormonal control of human colon carcinoma cell growth in serum-free medium. Proc Natl Acad Sci USA 1980; 77: 3464-8.

20 Harrison JD, Watson S, Morris DL. The effect of sex hormones and tamoxifen on the growth of human gastric and colorectal cancer cell lines. Cancer 1989; 63: 2148-51.

21 Kiss R, Salmon I, Pauwels O, Gras S, Danguy A, Etievant $C$, et al. In vitro influence of gastrin, oestradiol and gonadoliberin-releasing hormone on HCT-15 and LoVo human colorectal neoplastic cell proliferation. Eur $\mathcal{f}$ Cancer 1991; 27: 1268-74.

22 Culouscou JM, Remacle-Bonnet M, Garroste F, Marvaldi J, Pommier G. Simultaneous production of IGF-I and EGF competing growth factors by HT-29 human colon cancer cell lines. Int $f$ Cancer 1987; 40: 646-52.

23 Huschtscha L, Rozengurt E, Bodmer WF. Growth factor requirements of human colorectal tumour cells: relations to cellular differentiation. Eur f Cancer 1991; 27: 1680-4.

24 Meggouh F, Lointier P, Pezet D, Saez S. Status of sex steroid hormone receptors in large bowel cancer. Cancer 1991; 67: 1964-70.

25 Koenders PG, Peters WHM, Wobbes Th, Beex LVAM, Nagengast FM, Benraad ThJ. Epidermal growth factor receptor levels are lower in carcinomatous than in normal colorectal tissue. Br f Cancer 1992; 65: 189-92.

26 Yasui W, Sumiyoshi H, Hata J, Kameda T, Ochiai A, Ito H, et al. Expression of epidermal growth factor receptor in human gastric and colonic carcinomas. Cancer Res 1988; 48: $137-41$.

27 Frucht H, Gazdar AF, Park JA, Oie H, Jensen RT. Characterization of functional receptors for gastrointestinal hormones on human colon cancer cells. Cancer Res 1992; 52: 1114-22

28 Mosman T. Rapid colorimetric assay for cellular growth and survival: application to proliferation and cytotoxicity assays. F Immunol Methods 1983; 65: 55-63.

29 Carmichael J, De Graff WG, Gazdar AF, Minna JD, Mitchell B. Evaluation of a tetrazolium-based semiautomated colorimetric assay: assessment of chemosensitivity testing. Cancer Res 1987; 47: 936-42.

30 Pauwels $\mathrm{O}$, Kiss R. Digital morphonuclear analyses of sensitive versus resistant neoplastic cells to vinca-alkaloid, alkylating and intercalating drugs. Cytometry 1991; 12: 388-97.

31 Leibovitz A, Stinson JC, McCombs WB, McCoy CE, Mazur KC, Mabry ND. Classification of human colorectal adenocarcinoma cell lines. Cancer Res 1976; 36: 4562-9.

32 Barranco SC, Townsend CM, Casartelli C, Macik BG, Burger NL, Boerwinkle WR, et al. Establishment and characterization of an in vitro model system for human adenocarcinoma of the stomach. Cancer Res 1983; 43: 1703-9.

33 Nelson-Rees WA, Kniazeff AJ, Darby NB. Debut and accumulation of centric fusion products: an index to age of certain cell lines. Cytogenetics 1967; 6: 436-50.

34 Dexter DL, Barbosa JA Calabresi PN. Dimethyl formamide-induced alteration of cell culture characteristics and loss of tumoregenicity in cultured human colon carcinoma cells. Cancer Res 1979; 39: 1020-5.

35 O'Donnel RW, Cockerell GL. Establishment and biological properties of a guinea pig colonic adenocarcinoma cell line induced by $\mathrm{N}$-methyl-N-nitrosourea. Cancer Res 1981; 41: 2372-7

36 Quinn LA, Moore GE, Morgan RT, Woods LK. Cell lines from human colon carcinoma with unusual cell products, double minutes, and homogeneously staining regions. Cancer Res 1979; 39: 4914-24.

37 Rutzky LP, Giovanella BC, Tom BH, Kaye CI, Noguchi PD, Kahan BD. Characterization of a human colonic adenocarcinoma cell line LS123. In Vitro Cell Dev Biol 1983; 19: $99-107$.

38 Park JG, Oie HK, Sugarbaker PH, Henslee JG, Chen TR, Johnson BE, et al. Characteristics of cell lines established from human colorectal carcinoma. Cancer Res 1987; 47: 6710-8.

39 Fogh J, Trempe G. New human tumor cell lines. In: Fogh J, ed. Human tumor cells in vitro. New York: Plenum Press, 1975: 115-59.

40 Semple TU, Quinn LA, Woods LK, Moore GE. Tumor and lymphoid cell lines from a patient with carcinoma of the colon for a cytotoxicity model. Cancer Res 1978; 38: 1345-55.

41 Stevens RH, Brooks GP, Osborne JW, Englund CW, White DW. Lymphocyte cytotoxicity in X-irradiation-induced Denocarcinoma of the rat small bowel. I. Measurement adenocarcinoma of the rat small bowel. I. Measurement of target cell destruction by release of radioiodinated membrane proteins: b

42 Petricciani JC, Wallace RE, McCoy DW. A comparison of three in vivo assays for cell tumorigenicity. Cancer Res 1974; 34: 105-8. 
43 Brattain MG, Fine WD, Khaled FM, Thompson J, Brattain DE. Heterogeneity of malignant cells from a human colonic carcinoma. Cancer Res 1981; 41. $1751-6$.

44 Tom BH, Rutzky LP, Jakstys MM, Oyasu R, Kaye CI, Kahan BD. Human colonic adenocarcinoma cells. In Vitro Cell Dev Biol 1976; 12: 180-91.

45 Franks LM, Hemmings VJ. A cell line from an induced carcinoma of mouse rectum. F Pathol 1978; 124: 35-8.

46 Tompkins WAF, Watrach AM, Schmale JD, Schultz RM, Harris JA. Cultural and antigenic properties of newly established cell strains derived from adenocarcinomas of the human colon and rectum. $\mathfrak{f}$ Natl Cancer Inst 1974; 52: the human

47 Fogh J, Wright WC, Loveless JD. Absence of HeLa cell contamination in 169 cell lines derived from human
tumors. $¥$ Natl Cancer Inst 1977 ; 58: 209-14.

48 Fogh J, Fogh JM, Orfeo T. One hundred and twenty-seven cultured human tumor cell lines producing tumors in nude mice. F Natl Cancer Inst 1977; 59: 221-5.

49 Murakami H, Masui H. Hormonal control of human colorectal cell growth in serum-free medium. Proc Natl Acad Sci USA 1980; 77: 3464-8.

50 Rubinstein LV, Shoemaker RH, Paull KD, Simon RM, Tosimi S, Skehan $\mathrm{P}$, et al. Comparison of in vitro anticancer-drug-screening data generated with tetrazolium assay versus a protein assay against a diverse panel of human tumor cell lines. $¥$ Natl Cancer Inst 1990; 82: human t113-8.

51 Skehan Ph, Storeng R, Scudiero D, Monks A, McMahon J Vistica $\mathrm{D}$, et al. New colorimetric cytotoxicity assay for anticancer-drug screening. $\mathcal{F}$ Natl Cancer Inst 1990; 82: 1107-12.

52 Vistica DT, Skehan Ph, Scudiero D, Monks A, Pittman A Boyd MR. Tetrazolium-based assays for cellular viability: a critical examination of selected parameters affecting formazan production. Cancer Res 1991; 51: 2515-20.

53 Bhat NR, Hauser KF, Kindy MS. Cell proliferation and protooncogene induction in oligodendroglial progenitors. F Neurosci Res 1992; 32: 340-9.

54 Kiss R, de Launoit Y, Wouters W, Deslypere JP, Lescrainier JP, Paridaens R, et al. Inhibitory action of androstenedione on the proliferation and cell cycle kinetics of aromatase-free MXT and MCF-7 mammary tumor cell lines. Eur f Cancer Clin Oncol 1989; 25: 837-43.

55 Rubin NH, Singh P, Alinder G, Greeley GH Jr, Rayford PL, Rietveld WJ, et al. Circadian rhythms in gastrin receptors in rat fundic stomach. Dig Dis Sci 1988; 33: 931-7.

56 Speir GR, Takeuchi K, Peitsch W, Johnson LR. Mucosal gastrin receptor. VII. Up- and down-regulation. $A m \mathcal{F}$ Physiol 1982; 5: G243-9.

57 Ledda-Columbano GM, Columbano A. Apoptosis and hepatocarcinogenesis. In: Tomei LD, Cope FO, eds Apoptosis: the molecular basis of cell death. Current Communications in Cell \& Molecular Biology. Cold Spring Harbor Laboratory Press 1991: 101-19.

58 Szende B, Schally AV, Comaru-Schally AM, Redding TW, Srkalovic G, Groot $\mathrm{K}$, et al. Cellular and molecular aspects of apoptosis in experimental tumors of animals treated with analogs of LHRH and somatostatin. In Tomei LD, Cope FO, eds. Apoptosis: the molecular basis of cell death. Current Communications in Cell \& Molecular Biology. Cold Spring Harbor Laboratory Press, 1991: 139-55.

59 Gerschenson LE, Rotello RJ. Apoptosis and cell proliferation are terms of the growth equation. In: Tomei LD, Cope FO, eds. Apoptosis: the molecular basis of cell Cope FO, eds. Apoptosis: the molecular basis of cell
death. Current Communications in Cell \& Molecular Biology. Cold Spring Harbor Laboratory Press, 1991: Biology.

60 Buttyan $R$. Genetic response of prostate cells to androgen deprivation: insights into the cellular mechanism of apoptosis. In: Tomei lar basis of cell death. Current Communications in Cell \& Molecular Biology. Cold Spring Harbor Laboratory 